Contents available at: Sri Lanka Journals Online

\title{
Effect of Indian Ocean Dipole (IOD) Events on the Second Inter-monsoonal Rainfall in the Wet Zone of Sri Lanka
}

\author{
A.B. Abeysekera ${ }^{*}$, B.V.R. Punyawardena1 ${ }^{1}$ B. Marambe' ${ }^{2}$ I.M.S.P. Jayawardena ${ }^{3}$, T. Sivananthawerl ${ }^{2}$ and $^{2}$ \\ V.N.M. Wickramasinghe ${ }^{1}$ \\ ${ }^{1}$ Natural Resources Management Centre, Department of Agriculture, Peradeniya, Sri Lanka. \\ 2 Department of Crop Science, Faculty of Agriculture, University of Peradeniya, Sri Lanka. \\ ${ }^{3}$ Department of Meteorology, Colombo, Sri Lanka.
}

\section{ARTICLE INFO}

\section{Article history:}

Received: 15 August 2020

Revised version received: 30 November 2020

Accepted: 26 January 2021

Available online: 30 July 2021

\section{Keywords:}

Dipole Mode Index

Indian Ocean Dipole

Rainfall variability

Second inter-monsoon rainy season

Wet zone

\section{Citation:}

Abeysekera, A.B., Punyawardena, B.V.R., Marambe, B., Jayawardena, I.M.S.P., Sivananthawerl, T. and Wickramasinghe V.N.M. (2021). Effect of Indian Ocean Dipole (IOD) events on the second inter-monsoonal rainfall in the Wet Zone of Sri Lanka. Tropical Agricultural Research, 32(3): 287-297.

DOI: http://doi.org/10.4038/tar.v32i3.8492

Abeysekera, A.B.

https://orcid.org/0000-0001-7318-4419

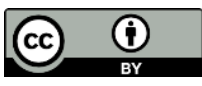

\section{ABSTRACT}

The climatic variations in the Indian Ocean have a strong relationship with the rainfall anomaly of Sri Lanka. Indian Ocean Dipole (IOD) is an ocean-atmospheric coupled phenomenon associated with an east-west gradient in the tropical Indian Ocean Sea Surface Temperature (SST) anomalies. Identifying the impact of IOD phenomenon on the spatial and temporal variation of the rainfall pattern is a useful tool for seasonal climate forecasting. The present study examined the influence of IOD on the Second Inter-monsoon (SIM) rains of the Wet zone (WZ) of Sri Lanka. Considering 16 rain-gauge locations scattered in the WZ of Sri Lanka covering nine Agro-ecological Regions (AERs), daily rainfall time series for 44-years (1976-2019) were collected. The IOD-positive and IOD-negative years were extracted based on the Dipole Mode Index (DMI) over the neutral years. Five rainfall indices, namely, cumulative rainfall, the maximum rainfall received within a day, number of wet days, heavy rainfall events and the maximum consecutive dry days were statistically analysed. The results revealed a significant positive anomaly of mean cumulative rainfall in the SIM season during the IOD-positive years while in IOD-negative years this anomaly was negative $(\mathrm{p}<0.05)$. An apparent increase or decrease of number of wet days and heavy rainfall events was observed during IOD-positive or IOD-negative years, respectively. However, the mean maximum consecutive dry days showed a distinct negative anomaly with the positive IOD events and positive anomaly with the negative IOD events. Further investigations are suggested to elucidate the El Niño Southern Oscillation (ENSO)-induced anomalous variation over IOD impacts.

\footnotetext{
* Corresponding author: arunikasekera@gmail.com
} 


\section{INTRODUCTION}

Indian Ocean Dipole (IOD) is an Oceanatmosphere interaction that may exemplify a characteristic internal mode of the Indian Ocean climate system (Saji et al., 1999; Webster et al., 1999). It is associated with the Sea Surface Temperature (SST) anomaly between two poles in the south-eastern and western equatorial Indian Ocean (Ashok et al., 2001; Yamagata et al., 2002). Similar to the dominant mode of oceanatmosphere interaction in the tropical Pacific; El Niño Southern Oscillation (ENSO), IOD also has three phases, namely, neutral, positive (warm) and negative (cold) (Kousky and Higgins, 2007; McPhaden et al., 2006; Philander, 1985). The positive phase of the IOD (associated with a warm SST) leads to enhanced rainfall in the western Indian Ocean and diminished rainfall in the south eastern Indian Ocean; while the opposite is true for the negative phase (Saji et al., 1999).

In the neutral phase, warm water from the upper equatorial Pacific Ocean is transferred to the Indian Ocean, resulting in a warm SST in the islands of Indonesia. Air rises above this area and falls allowing westerly winds to blow along the equator (Rao et al., 2002). During the positive IOD phase, westerly winds weaken along the equator allowing warm water to shift towards Africa. Changes in the winds also allow cool water to rise up from the deep ocean in the east. This sets up a temperature difference across the tropical Indian Ocean resulting in higher rainfall in the countries around the Arabian Sea. Westerly winds intensify along the equator during the negative phase, allowing warmer waters to concentrate near Australia. This sets up a temperature difference across the tropical Indian Ocean, with an aboveaverage rainfall over parts of southern Australia and Sumatra (Yuan et al., 2008; Aparna et al., 2012; Pentakota et al., 2012; BOM, Australia, 2020). An IOD situation is a complex phenomenon with multiple variants, i.e. whether they be called true dipoles, pseudo dipoles, IOD Modoki, etc. (Verdon-Kidd, 2018).

Several studies have been carried out in different countries, especially those closer to the Indian Ocean, to find out the impact of IOD on the rainfall pattern and thereby the weather changes such as floods and droughts. Clark et al. (2003) and Black et al. (2003) reported that the rainfall in October to December, along the coastal belt in Kenya and Tanzania, correlates strongly with SST in the Indian Ocean. Ashok et al. (2001) showed that a positive IOD plays an important role in increasing the Indian summer monsoon (ISMR) rainfall. Furthermore, the IOD influences the inter-annual rainfall variability over central Brazil and subtropical La Plata Basin during the austral spring (Chan et al., 2008). Through limited studies, a considerable influence of IOD events has been observed in the rainfall climatology of Sri Lanka (Zubair et al., 2003; Jayawardene et al., 2015).

Sri Lanka has four distinct rainfall seasons, namely, the first inter-monsoon (FIM), southwest monsoon (SWM), second inter-monsoon (SIM) and northeast monsoon (NEM) (Punyawardena, 2020). Based on these four rainfall seasons, the country has two cultivation seasons, i.e. Yala season comprising both FIM and SWM seasons (minor cultivating season; March - September) and Maha season comprising both SIM and NEM seasons (major cultivating season; October to February) (Punyawardena, 2020). During two monsoon seasons, rainfall is mainly received by the southwest and northeast monsoonal winds while during inter-monsoon periods, Sri Lanka receives rains by the convectional activity and its enhanced phase with the passage of the Inter Tropical Convergence Zone (ITCZ) on or near to Sri Lanka (Punyawardena, 2008). Land preparation and crop establishment activities are initiated with the onset of the inter-monsoon rains in each growing seasons. Therefore, the positive and negative anomalies of the rainfall pattern in the inter-monsoon seasons would directly affect the crop production during the Yala and Maha seasons. The SIM is the most important rainy season to the country where the island receives a well distributed rainfall within two months (October and November), which is about 30\% of the total annual rainfall (Chandrapala, 2007).

Wet zone (WZ) covers the south-western part of the low lands and central highlands of Sri Lanka, which receives over $2,500 \mathrm{~mm}$ of average annual rainfall (Punyawardena et al., 2013). Though the major irrigated paddy-growing areas are not located in the $\mathrm{WZ}$, the rainfed paddy, three major planation crops (tea, rubber and coconut), export agricultural crops, and vegetables are mainly established in the $\mathrm{WZ}$ depending on the rainfall pattern (Punyawardena et al., 2003). Further, the WZ precipitation causes a considerable impact on the economic progress of Sri Lanka as the main source of energy is hydropower (Jayawardene et al., 2015). Therefore, it is important to ascertain the rainfall variation in the WZ of Sri Lanka under the effect of IOD in order to enhance the skill of weather predictions enabling to make appropriate on-farm decisions well before the onset of the Maha season. 


\section{METHODOLOGY}

Daily rainfall data were collected from 16 meteorological observation stations scattered throughout the WZ of Sri Lanka, representing nine different Agro-ecological Regions (AERs), for a period of 44 years from 1976 to 2019 (Figure 1). Data were sourced from the Natural Resources Management Centre of the Department of Agriculture, Department of Meteorology, and the Tea Research Institute of Sri Lanka.

Several Ocean-atmospheric indices have been used to investigate the IOD events such as SST, Sea
Sub-surface Temperature, Sea Surface Heights, surface zonal winds and velocity potential $(X)$ fields (Ashok et al., 2001; Zubair et al., 2003; Rao and Yamagata, 2004; Chan et al., 2008; Xin-Yu et al., 2015). For the present study, SST defined by the National Oceanic and Atmospheric Administration (NOAA) of the United States Climate Prediction Centre (CPC) was considered (Reynolds et al., 2007). Intensity of the IOD was represented by the anomalous SST gradient between the western equatorial Indian Ocean (50E-70E and $10 \mathrm{~S}-10 \mathrm{~N})$ and the south eastern equatorial Indian Ocean (90E-110E and 10S-0N) (Figure 2).

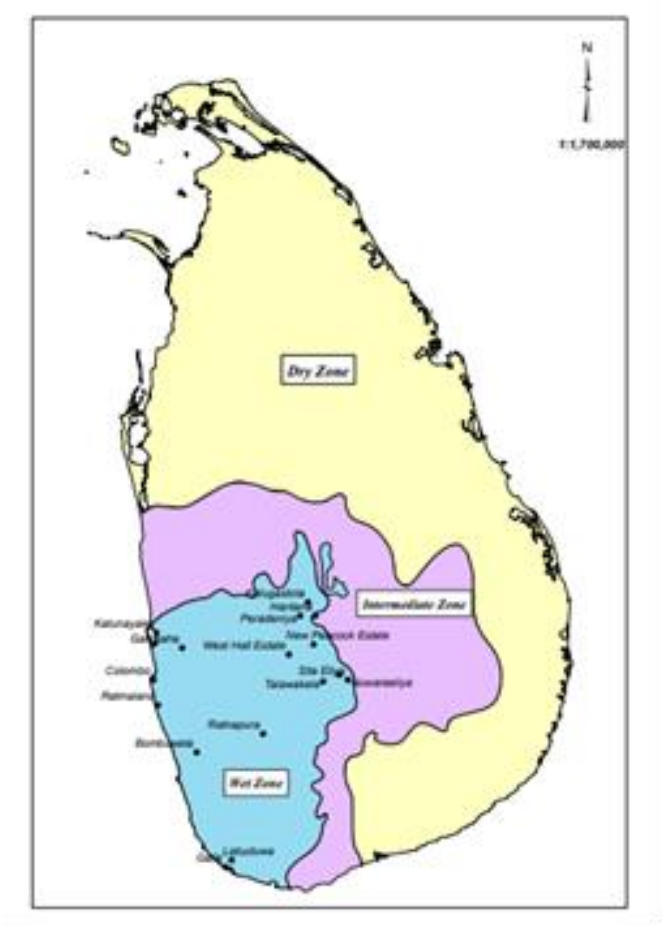

Figure 1: Rain gauge location map in the Wet zone considered for the study

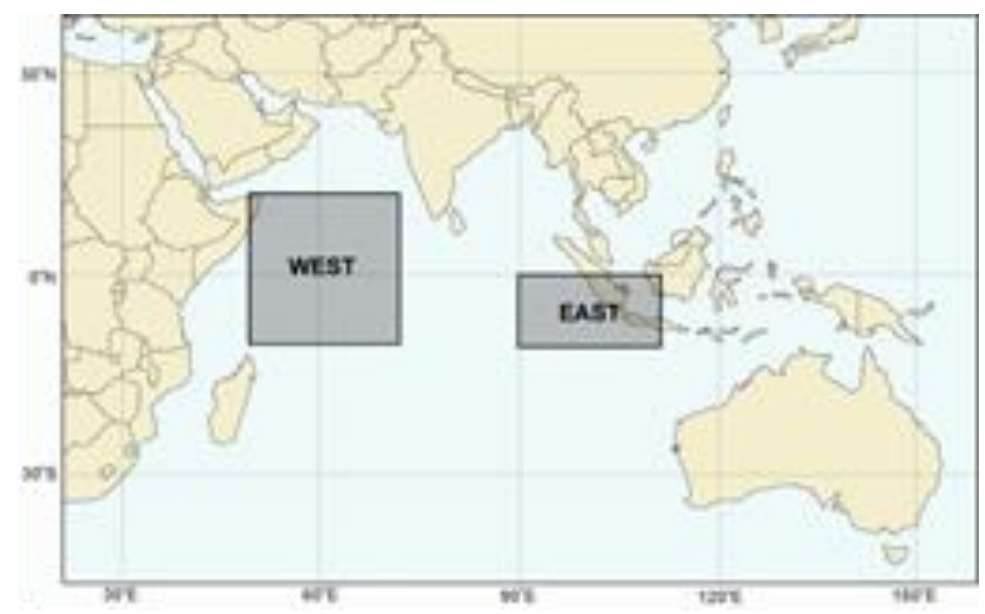

Figure 2: The two poles in the Indian Ocean (Image credit: BOM, Australia) 
Table 1: Rainfall indices used in the study

\begin{tabular}{ll}
\hline Index & Definition \\
\hline Cumulative rainfall $(\mathrm{mm})$ & Total rainfall received during the season \\
Maximum rainfall per day $(\mathrm{mm})$ & Maximum value of rainfall received within a day, during the season \\
Number of wet days & Total number of days that received rainfall $>1 \mathrm{~mm}$ during the season \\
Number of heavy rainfall events & $\begin{array}{l}\text { Total number of days that received rainfall higher than the value of } \\
90^{\text {th }} \text { percentile of the standard average period of this study }\end{array}$ \\
Maximum consecutive dry days & $\begin{array}{l}\text { The largest count of consecutive days that received rainfall }<1 \mathrm{~mm} \\
\text { during the season }\end{array}$ \\
\hline
\end{tabular}

This gradient is named as Dipole Mode Index (DMI). When the DMI is positive, the phenomenon is referred to as the IOD-positive and while a negative DMI is referred to as the IOD-negative (Saji et al., 1999; Webster et al., 1999). The periodically updated east and west SST anomalies, published by Physical Science Laboratory, NOAA (DMI: Standard PSL) was considered for the present study (https://psl.noaa.gov/gcos_wgsp/ Timeseries/DMI/). Different IOD related studies shows a substantial variation in selecting the IOD events depending the spatial and temporal difference (Verdon-Kidd, 2018; Chan et al., 2008; Hong, 2008). For the present study, the operationally used value of above $+0.4{ }^{\circ} \mathrm{C}$ was considered as the positive IOD events and below $-0.4{ }^{\circ} \mathrm{C}$ was considered as the negative IOD event (http://www.bom.gov.au/climate/enso/\#tabs=In dian-Ocean). The DMI range of $-0.4{ }^{\circ} \mathrm{C}$ to $+0.4{ }^{\circ} \mathrm{C}$ is the IOD-neutral period. Based on this threshold values, IOD-positive, IOD-negative and neutral years were identified for the four rainfall seasons of Sri Lanka.

Five rainfall indices were considered to find the effect of IOD events on the rainfall variability of the country (Table 1). One-way ANOVA, Dunnett's test and Cross Tabulation-Chi-square test were used $(p=0.05)$ to investigate the statistical significance, using Minitab statistical software.

\section{RESULTS AND DISCUSSION}

The IOD-positive and IOD-negative years during the study period 1976-2019 within the four rainfall seasons are shown in Table 2 . There were only 2 or 3 IOD events during NEM and FIM seasons in both positive and negative phases of the IOD. This clearly indicates that statistically acceptable number of IOD events does not exist during the NEM and FIM seasons to proceed with further analysis. Within an IOD year, IOD events usually started around May or June, peaked in October and then decayed in December (Saji et al., 1999).

Among the two rainfall seasons (SIM and SWM) where IOD was effective, only SIM season showed statistically significant observations, with a peak of IOD events within a year. The SWM season did not show any apparent increasing or decreasing trends of IOD events (data not shown). Therefore, the present study was mainly focused on the effect of IOD events on the SIM season. Previous studies have also revealed a positive anomaly of rainfall around the Arabian Sea during October-November period under the influence of a positive IOD (Black, 2005; Black et al., 2003; Chan et al., 2008). Zubair et al. (2003), using monthly datasets from 1869-2000, also reported an enhancement of Maha season rainfall during the positive IOD phase. Ashok et al. (2001) discovered that the ENSO-Indian Summer Monsoon rainfall (ISMR) correlation is low (high), when the IOD-ISMR correlation is high (low).

\section{Comparison of the Mean Cumulative Rainfall}

The spatial distribution of positive and negative mean cumulative rainfall anomalies over the neutral years are illustrated in Figure 3. An anomalous variation was prominent in Upcountry WZ and Mid-country WZ mainly during the IOD-positive years.

The average of all 16 locations considered in the study showed a significant increase in mean cumulative rainfall during IOD-positive years while a significant decrease in IOD-negative years $(\mathrm{p}<0.05)$ (Table 3). Among all locations studied, the locations in the WU3 AER showed a significant positive anomaly. 
Table 2: IOD-positive and IOD-negative years within four rainfall seasons during the study period

\begin{tabular}{|c|c|c|c|c|c|c|c|}
\hline \multicolumn{4}{|c|}{ IOD-positive Years } & \multicolumn{4}{|c|}{ IOD-negative Years } \\
\hline FIM & SWM & SIM & NEM & FIM & SWM & SIM & NEM \\
\hline 2010 & 1983 & 1982 & 1998 & 1983 & 1980 & 1980 & 1978 \\
\hline \multirow[t]{7}{*}{2017} & 1994 & 1994 & 2019 & 1992 & 1981 & 1984 & 1983 \\
\hline & 1997 & 1997 & & & 1989 & 1996 & 1985 \\
\hline & 2012 & 2006 & & & 1992 & 1998 & \\
\hline & 2015 & 2011 & & & 1996 & & \\
\hline & 2017 & 2015 & & & & & \\
\hline & 2019 & 2018 & & & & & \\
\hline & & 2019 & & & & & \\
\hline
\end{tabular}

Source: https://psl.noaa.gov/gcos_wgsp/Timeseries/DMI/; IOD-positive years: anomalous east west SST gradient is $>\left(+0.4{ }^{\circ} \mathrm{C}\right)$; IOD-negative years: anomalous east west SST gradient $<\left(-0.4{ }^{\circ} \mathrm{C}\right)$; FIM: First Inter-monsoon; SWM: Southwest monsoon; SIM: Second Inter-monsoon and NEM: Northeast monsoon.
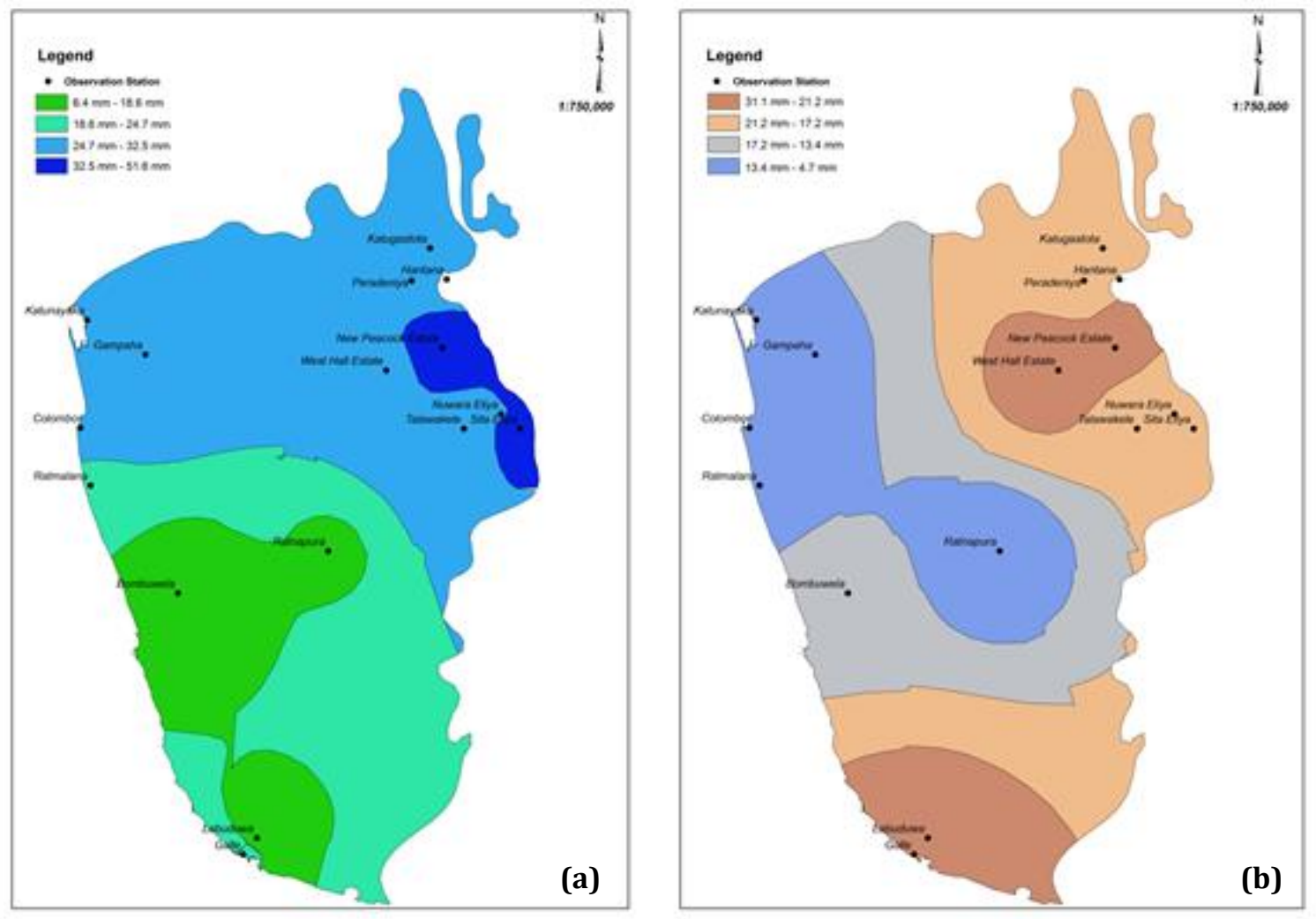

Figure 3: Spatial distribution pattern of mean cumulative rainfall anomaly during (a) IOD-positive years and (b) IOD-negative years.

The amount of water needed for crops can be supplied by rainfall, irrigation, or by a combination of both (Brouwer and Heibloem, 1986). Rainfed cultivation is prominent in the WZ as it receives a sufficient amount of rainwater during both cultivation seasons. The quantum of rainwater received is an important factor to be considered when planning a cropping season to select the crop variety and the extent of cultivation. The present study revealed that the quantum of rainfall received within the SIM period in the WZ is in the range of $430-867 \mathrm{~mm}$. During a positive IOD period, it has increased from 525 $1,120 \mathrm{~mm}$ and decreased to a range of $370-825$ mm during IOD-negative years (Table 3). Hence, if a positive IOD phase is predicted in a given year, excess soil moisture conditions in uplands and water-logging and/or flooding in low-lands can be expected during the SIM season. 
Table 3: Comparison of positive and negative IOD years with neutral years for mean cumulative rainfall (mm)

\begin{tabular}{lllll}
\hline Station & AER & Neutral & Positive & Negative \\
\hline Thalawakele & WU2a & 430.4 & $525.2^{\mathrm{ns}}$ & $372.9^{\mathrm{ns}}$ \\
Pussallawa (West Hall) & WU2b & 834.2 & $1030.0^{\mathrm{ns}}$ & $574.9^{\mathrm{ns}}$ \\
Pussallawa (New Peacock) & WU2b & 737.7 & $1119.0^{\mathrm{ns}}$ & $563.0^{\mathrm{ns}}$ \\
Nuwara Eliya & WU3 & 455.8 & $601.4^{\mathrm{s}}$ & $371.1^{\mathrm{ns}}$ \\
Sita Eliya & WU3 & 503.8 & $709.9^{\mathrm{s}}$ & $394.6^{\mathrm{ns}}$ \\
\hline Hantana & WM2b & 535.3 & $665.5^{\mathrm{ns}}$ & $380.0^{\mathrm{ns}}$ \\
Peradeniya & WM2b & 566.6 & $719.9^{\mathrm{ns}}$ & $491.9^{\mathrm{ns}}$ \\
Katugastota & WM3b & 559.3 & $692.3^{\mathrm{ns}}$ & $459.1^{\mathrm{ns}}$ \\
\hline Ratnapura & WL1a & 866.5 & $1005.7^{\mathrm{ns}}$ & $825.6^{\mathrm{ns}}$ \\
Bombuwela & WL1b & 800.8 & $859.8^{\mathrm{ns}}$ & $671.0^{\mathrm{ns}}$ \\
Labuduwa & WL2a & 716.5 & $762.3^{\mathrm{ns}}$ & $567.9^{\mathrm{ns}}$ \\
Galle & WL2a & 636.3 & $742.2^{\mathrm{ns}}$ & $437.8^{\mathrm{ns}}$ \\
Colombo & WL3 & 634.0 & $833.7^{\mathrm{ns}}$ & $589.2^{\mathrm{ns}}$ \\
Katunayake & WL3 & 650.5 & $853.9^{\mathrm{ns}}$ & $574.5^{\mathrm{ns}}$ \\
Gampaha-Henarathgoda & WL3 & 615.3 & $806.5^{\mathrm{ns}}$ & $541.8^{\mathrm{ns}}$ \\
Rathmalana & WL3 & 714.6 & $864.4^{\mathrm{ns}}$ & $627.2^{\mathrm{ns}}$ \\
\hline Average & & 641.1 & $799.5^{\mathrm{s}}$ & $527.7^{\mathrm{s}}$ \\
\hline
\end{tabular}

AER: Agro-ecological Regions; within a row, compared with the neutral years (separately with positive and negative IOD years), means followed by 'ns' are not significantly different and those followed by 's' are significantly different at $\mathrm{p}=0.05$.

Moreover, appropriate soil conservation measures should be adopted in sloping lands, especially in mid and up country regions of the WZ in such years. The IOD-negative years may not have a major impact on $\mathrm{WZ}$ crops, where even rice and tea being the crops that are highly influenced by variations of rainfall require a minimum of 200 $\mathrm{mm}$ of rainfall per month (De Costa, 2010).

\section{Comparison of the Mean Maximum Rainfall per day}

The mean values of the maximum rainfall received per day did not show a significant positive or negative anomaly during the IOD-positive period (Table 4). However, the IOD-negative years showed below average values for every selected location except at Gampaha-Henarathgoda.

According to the study, the mean maximum rainfall received per day during a neutral year ranged from 60 to $130 \mathrm{~mm}$. This range decreased to 51 - $124 \mathrm{~mm}$ during an IOD-negative phase (Table 4). Receipt of the maximum rainfall per day in a given location depends on several factors such as atmospheric pressure, wind speed and sheer, convectional activity, the position of the ITCZ, occurrence of low level atmospheric disturbances, and cyclonic storms resulting in high variability of daily rainfall during the SIM season
(Punyawardena, 2008). Therefore, the impact of IOD can be masked by these factors.

\section{Comparison of the Number of Wet Days}

There was an association between IOD-phases and the number of wet days in all selected locations $(\mathrm{p}=0.05)$ except in five locations, namely, Talawakele, Pussallawa-West Hall, Bombuwela, Labuduwa and Galle for IOD-positive years (Table 5). On average, $55.6 \%$ of the number of wet days were observed during the neutral years (range: $46.2 \%-63.6 \%$ ). This has increased to $62.9 \%$ with the positive impact of IOD phase (range: $56.4 \%$ $72.5 \%$ ) and decreased to $50.8 \%$ during an IODnegative period (range: $37.7 \%-67.6 \%$ ).

Distribution of rainfall received during the season is also an important information to find out whether the crop water requirement is being met by rainfall alone. The reduction of rainfall during the IOD-negative phase may not affect the crop performance in the WZ because of the prevailing relatively low evapotranspiration regime of the region. Monthly evapotranspiration rate ranges from $45.6 \mathrm{~mm}$ to $67.0 \mathrm{~mm}$ during SIM in the WZ (DOA, 2018). The present study also revealed that more than 15 consecutive days of receiving rainfall of $<1 \mathrm{~mm}$ was hardly observed even during the IOD-negative phase in the SIM season (Data not shown). 
Table 4: Comparison of positive and negative IOD years with neutral years for mean maximum rainfall (mm per day)

\begin{tabular}{|c|c|c|c|c|}
\hline Station & AER & Neutral & Positive & Negative \\
\hline Thalawakele & WU2a & 60.9 & $61.7^{\mathrm{ns}}$ & $51.0^{\mathrm{ns}}$ \\
\hline Pussallawa (West Hall) & WU2b & 90.1 & $89.3^{\text {ns }}$ & $62.9^{\mathrm{ns}}$ \\
\hline Pussallawa (New Peacock) & WU2b & 90.7 & $104.3^{\mathrm{ns}}$ & $73.7^{\mathrm{ns}}$ \\
\hline Nuwara Eliya & WU3 & 65.8 & $64.1^{\mathrm{ns}}$ & $62.2^{\mathrm{ns}}$ \\
\hline Sita Eliya & WU3 & 65.2 & $67.5^{\mathrm{ns}}$ & $58.5^{\mathrm{ns}}$ \\
\hline Hantana & WM2b & 73.3 & $79.5^{\mathrm{ns}}$ & $69.9^{\text {ns }}$ \\
\hline Peradeniya & WM2b & 74.3 & $78.8^{\text {ns }}$ & $66.9^{\text {ns }}$ \\
\hline Katugastota & WM3b & 79.8 & $76.3^{\mathrm{ns}}$ & $72.7^{\mathrm{ns}}$ \\
\hline Ratnapura & WL1a & 95.9 & $108.8^{\mathrm{ns}}$ & $94.4^{\mathrm{ns}}$ \\
\hline Bombuwela & WL1b & 128.5 & $114.2^{\mathrm{ns}}$ & $100.7^{\mathrm{ns}}$ \\
\hline Labuduwa & WL2a & 113.2 & $120.0^{\mathrm{ns}}$ & $90.0^{\mathrm{ns}}$ \\
\hline Galle & WL2a & 101.4 & $109.2^{\mathrm{ns}}$ & $85.9^{\text {ns }}$ \\
\hline Colombo & WL3 & 125.4 & $96.1^{\mathrm{ns}}$ & $95.1^{\mathrm{ns}}$ \\
\hline Katunayake & WL3 & 109.1 & $104.7^{\mathrm{ns}}$ & $92.6^{\mathrm{ns}}$ \\
\hline Gampaha-Henarathgoda & WL3 & 95.1 & $88.3^{\mathrm{ns}}$ & $96.7^{\mathrm{ns}}$ \\
\hline Rathmalana & WL3 & 130.0 & $97.1^{\mathrm{ns}}$ & $123.8^{\mathrm{ns}}$ \\
\hline Average & & 93.7 & $145.9^{\mathrm{ns}}$ & $81.1^{\mathrm{ns}}$ \\
\hline
\end{tabular}

AER: Agro-ecological Regions; within a row, compared with the neutral phase (separately with positive and negative IOD years), means followed by 'ns' are not significantly different at $\mathrm{p}=0.05$.

Table 5: Comparison of positive and negative IOD years with neutral years for number of wet days

\begin{tabular}{|c|c|c|c|c|c|c|}
\hline Station & AER & $\begin{array}{c}\text { Neutral } \\
\text { Total } \\
\text { number of } \\
\text { WD for the } \\
\text { total of } \\
1952 \text { days }\end{array}$ & $\begin{array}{c}\text { Positive } \\
\text { Total } \\
\text { number of } \\
\text { WD for the } \\
\text { total of } 488 \\
\text { days }\end{array}$ & $\begin{array}{c}\text { Negative } \\
\text { Total } \\
\text { number of } \\
\text { WD for the } \\
\text { total of } 244 \\
\text { days } \\
\end{array}$ & $\begin{array}{c}\begin{array}{c}\text { p value } \\
\text { for } \\
\text { positive } \\
\text { events }\end{array} \\
\end{array}$ & $\begin{array}{c}\begin{array}{c}p \text { value } \\
\text { for }\end{array} \\
\text { negative } \\
\text { events }\end{array}$ \\
\hline Talawakele & WU2a & 921 & 226 & 139 & 0.624 & 0.316 \\
\hline Pussallawa (West Hall) & WU2b & 1241 & 295 & 165 & 0.201 & 0.214 \\
\hline Pussallawa (New Peacock) & WU2b & 964 & 221 & 87 & $0.000^{*}$ & 0.072 \\
\hline Nuwara Eliya & WU3 & 1125 & 316 & 124 & $0.004^{*}$ & $0.043^{*}$ \\
\hline Sita Eliya & WU3 & 1135 & 336 & 133 & $0.000^{*}$ & 0.278 \\
\hline Hantana & WM2b & 818 & 242 & 92 & $0.000^{*}$ & $0.012 *$ \\
\hline Peradeniya & WM2b & 1005 & 282 & 120 & $0.013^{*}$ & 0.497 \\
\hline Katugastota & WM3b & 1082 & 299 & 123 & $0.020^{*}$ & 0.137 \\
\hline Ratnapura & WL1a & 1168 & 337 & 135 & $0.003^{*}$ & 0.052 \\
\hline Bombuwela & WL1b & 1150 & 299 & 128 & 0.343 & 0.054 \\
\hline Labuduwa & WL2a & 1039 & 284 & 130 & 0.197 & 0.623 \\
\hline Galle & WL2a & 1046 & 275 & 124 & 0.273 & 0.414 \\
\hline Colombo & WL3 & 1055 & 320 & 109 & $0.000^{*}$ & $0.006^{*}$ \\
\hline Katunayake & WL3 & 1042 & 308 & 115 & $0.000^{*}$ & 0.065 \\
\hline Gampaha-Henarathgoda & WL3 & 918 & 313 & 108 & $0.000^{*}$ & 0.208 \\
\hline Ratmalana & WL3 & 1112 & 317 & 118 & $0.001^{*}$ & $0.011^{*}$ \\
\hline
\end{tabular}

AER: Agro-ecological Region; WD: Wet days; '*’ Values are significant at $\mathrm{p}=0.05$

\section{Comparison of heavy rainfall events}

There was an association between IOD-phases and number of heavy rainfall events in all considered locations ( $\mathrm{p}=0.05)$, except at Pussallawa-West Hall, Ratnapura, Bombuwela, Labuduwa and Galle for IOD-positive years (Table 6). On average,
$10.7 \%$ of the heavy rainfall events were observed during the neutral years (range: 8.6\% - 11.8\%). This has increased to $15 \%$ with the positive impact of IOD phase (range: $11.9 \%$ - 19\%) and decreased to $8.5 \%$ during an IOD-negative period (range: $5.7 \%-11.5 \%$ ). 
Table 6: Comparison of positive and negative IOD years with neutral years for heavy rainfall events

\begin{tabular}{|c|c|c|c|c|c|c|}
\hline Station & AER & $\begin{array}{c}\text { Neutral } \\
\text { Total HRE } \\
\text { for the total } \\
\text { of } 1952 \\
\text { events }\end{array}$ & $\begin{array}{c}\text { Positive } \\
\text { Total HRE } \\
\text { for the total } \\
\text { of } 488 \\
\text { events }\end{array}$ & $\begin{array}{c}\text { Negative } \\
\text { Total HRE } \\
\text { for the total } \\
\text { of } 244 \\
\text { events }\end{array}$ & $\begin{array}{c}\begin{array}{c}p \text { value } \\
\text { for }\end{array} \\
\text { positive } \\
\text { events }\end{array}$ & $\begin{array}{c}\begin{array}{c}p \text { value } \\
\text { for }\end{array} \\
\text { negative } \\
\text { events }\end{array}$ \\
\hline Talawakele & WU2a & 182 & 56 & 19 & $0.015^{*}$ & 0.091 \\
\hline Pussallawa (West Hall) & WU2b & 223 & 71 & 16 & 0.058 & $0.021^{*}$ \\
\hline Pussallawa(New Peacock) & WU2b & 188 & 58 & 15 & $0.000 *$ & 0.305 \\
\hline Nuwara Eliya & WU3 & 221 & 82 & 23 & $0.001 *$ & 0.374 \\
\hline Sita Eliya & WU3 & 231 & 86 & 17 & $0.001 *$ & $0.024^{*}$ \\
\hline Hantana & WM2b & 152 & 58 & 14 & $0.000 *$ & 0.129 \\
\hline Peradeniya & WM2b & 182 & 68 & 18 & $0.003^{*}$ & 0.319 \\
\hline Katugastota & WM3b & 214 & 72 & 18 & $0.020 *$ & 0.086 \\
\hline Ratnapura & WL1a & 197 & 64 & 28 & 0.089 & 0.613 \\
\hline Bombuwela & WL1b & 226 & 58 & 25 & 0.850 & 0.538 \\
\hline Labuduwa & WL2a & 210 & 64 & 18 & 0.215 & 0.076 \\
\hline Galle & WL2a & 207 & 67 & 16 & 0.051 & $0.048^{*}$ \\
\hline Colombo & WL3 & 220 & 76 & 27 & $0.009 *$ & 0.924 \\
\hline Katunayake & WL3 & 198 & 68 & 24 & $0.016^{*}$ & 0.881 \\
\hline Gampaha-Henarathgoda & WL3 & 203 & 75 & 26 & $0.004^{*}$ & 0.970 \\
\hline Ratmalana & WL3 & 217 & 74 & 26 & $0.014 *$ & 0.829 \\
\hline
\end{tabular}

AER: Agro-ecological Region, HRE: Heavy Rainfall Events; * Values are significant at $\mathrm{p}=0.05$.

Table 7: Comparison of positive and negative IOD years with neutral years for mean maximum consecutive dry days

\begin{tabular}{llccc}
\hline Station & AER & Neutral & Positive & Negative \\
\hline Thalawakele & WU2a & 7 & $5^{\text {ns }}$ & $9^{\text {ns }}$ \\
Pussallawa (West Hall) & WU2b & 7 & $6^{\text {ns }}$ & $6^{\text {ns }}$ \\
Pussallawa (New Peacock) & WU2b & 8 & $5^{\text {ns }}$ & $10^{\text {ns }}$ \\
Nuwara Eliya & WU3 & 8 & $6^{\text {ns }}$ & $10^{\text {ns }}$ \\
Sita Eliya & WU3 & 8 & $5^{\text {ns }}$ & $9^{\text {ns }}$ \\
\hline Hantana & WM2b & 8 & $7^{\text {ns }}$ & $9^{\text {ns }}$ \\
Peradeniya & WM2b & 8 & $7^{\text {ns }}$ & $9^{\mathrm{s}}$ \\
Katugastota & WM3b & 8 & $5^{\text {ns }}$ & $10^{\text {ns }}$ \\
\hline Ratnapura & WL1a & 7 & $5^{\text {ns }}$ & $10^{\mathrm{s}}$ \\
Bombuwela & WL1b & 7 & $5^{\text {ns }}$ & $8^{\text {ns }}$ \\
Labuduwa & WL2a & 8 & $7^{\text {ns }}$ & $10^{\text {ns }}$ \\
Galle & WL2a & 8 & $5^{\text {ns }}$ & $12^{\text {ns }}$ \\
Colombo & WL3 & 8 & $4^{\mathrm{s}}$ & $12^{\text {ns }}$ \\
Katunayake & WL3 & 8 & $5^{\text {ns }}$ & $10^{\text {ns }}$ \\
Gampaha-Henarathgoda & WL3 & 11 & $5^{\text {ns }}$ & $10^{\text {ns }}$ \\
Rathmalana & WL3 & 7 & $4^{\mathrm{s}}$ & $9^{\mathrm{ns}}$ \\
\hline Average & & 8 & $5^{\mathrm{s}}$ & $10^{\mathrm{s}}$ \\
\hline
\end{tabular}

AER: Agro-ecological Regions; within a row, compared with the neutral phase (separately with positive and negative IOD years), means followed by 'ns' are not significantly different and those followed by 's' are significantly different at $\mathrm{p}=0.05$.

Black et al. (2003) has reported that extreme short rains are associated with increasing IOD events in East Africa. Heavy rainfall events can be considered as receiving intense rains within a short period of time. Receiving $>25 \mathrm{~mm}$ of rainfall per hour is considered as an "erosive rain"
(Punyawardena, 2008). High intense rains result in soil erosion especially in the sloping terrain in the WZ (i.e., Mid and Up country WZ). Therefore, if an IOD event is predicted, agro-met advisories may emphasize on the importance of adopting soil 
conservation measures in landscapes that are prone to soil erosion and land degradation.

\section{Comparison of the Mean Maximum Consecutive Dry Days}

An apparent reduction of the mean value of the maximum consecutive dry days was observed with the positive IOD events in all selected locations. Colombo and Ratmalana in WL3 AER showed a significant decrease of the maximum consecutive dry days $(\mathrm{p}<0.05)$. During the IODnegative period, 14 out of 16 locations showed an increasing trend in the maximum consecutive dry days, where a significant increase $(p<0.05)$ was reported from Ratnapura (Table 7).

In the IOD-neutral phase, the maximum consecutive dry days ranged from 7 to 11, which decreased to 4-7 days during the IOD-positive phase, and increased to 6-12 days during the IOD negative phase (Table 7). In general, the maximum consecutive dry days is not a meaningful indicator for the $\mathrm{WZ}$ as rainfall has exceeded the evapotranspiration demand (DOA, 2018).

The IOD cannot be viewed in isolation from the ENSO. Instead, it is assumed that in some years, a strong ENSO forcing can create a bias in the Indian Ocean-coupled system (Ashok et al., 2001; Black et al., 2003; Zubair et al. in 2003; Chan et al., 2008). As for the SIM season considered, five El Nino years and one La Nina year were observed during the IOD-positive period and one La Nina event was recorded during the IOD-negative period (Abeysekera et al., 2017).

A positive anomaly of rainfall has been recorded during the El Nino years in the WZ of Sri Lanka for the SIM season while a below normal rainfall was recorded during the La Nina period (Hapuarachchi and Jayawardena, 2015; Abeysekera et al., 2019). The locations and periods used in the previous studies (Abeysekera

\section{RERERENCES}

Abeysekera, A.B., Punyawardena, B.V.R., Marambe, B., Jayawardena, I.M.S.P., Wickramasinghe, V.N.M., Senarathna, E.D.D.L. and Wijerathna, W.M.V.S. (2019). Effect of El Niño Southern Oscillation (ENSO) events on inter-seasonal variability of rainfall in Wet and Intermediate zones of Sri Lanka. Tropical Agriculturist, 167(1), 14-27. et al., 2017; 2019) were the same as in the present study. Therefore, further investigations are needed to understand the interaction effects of IOD and ENSO on the all four rainfall season of Sri Lanka.

\section{CONCLUSION}

The present study identified the impact of the IOD events on the rainfall climatology of second intermonsoon seasonal rainfall in the Wet zone of Sri Lanka. A robust statistical analysis revealed an apparent increase in cumulative seasonal rainfall, mean number of wet days and heavy rainfall events with the positive IOD events. The opposite of this was observed during IOD negative events. No discernible changes were observed for the mean maximum rainfall received per day within the season. The mean maximum consecutive dry days showed a distinct negative anomaly with the positive IOD events and positive anomaly with the negative IOD events. The influence of the IOD phenomenon on the Wet zone during the SIM season was evident in this study suggesting its usefulness as a tool for seasonal climate forecasting and agro-met advisories.

\section{ACKNOWLEDGEMENTS}

Authors wish to express their sincere gratitude to Mr. A. K. Hettiarachchi, Natural Resources Management Centre (NRMC), Department of Agriculture, Peradeniya for producing the rain gauge location map and the maps of spatial distribution pattern of mean cumulative rainfall anomaly. The support given by the staff of the Division of Agro-climatology and Climate change at the NRMC is also greatly appreciated.

Abeysekera, A.B., Punyawardena, B.V.R., Sivananthawerl T. and Premalal, K.H.M.S. (2017). Inter seasonal variability of the rainfall pattern in the Dry Zone of Sri Lanka with the influence of El Nino Southern Oscillation (ENSO). Annals of the Sri Lanka Department of Agriculture. 19(1), 139-167.

Aparna, S.G., McCreary, J. P., Shankar, D. and Vinayachandran, P.N. (2012). Signatures of Indian Ocean Dipole and El Niño-Southern Oscillation events in sea level variations in the 
Bay of Bengal. Journal of Geophysical Research. 117, C10012.

Ashok, K., Guan, Z. and Yamagata, T. (2001). Impact of the Indian Ocean Dipole on the Relationship between the Indian Monsoon Rainfall and ENSO. Geophysical Research Letters. 28(23), 4499-4502.

Black, E. (2005). The relationship between Indian Ocean sea-surface temperature and East African rainfall. Philosophical Transactions. $363,43-47$.

Black, E., Slingo, J. and Sperber, K.R. (2003). An Observational Study of the Relationship between Excessively Strong Short Rains in Coastal East Africa and Indian Ocean SST. Monthly Weather Review. 131, 74-94.

BOM, Australia. (2020). Available at http://www.bom.gov.au/climate/iod/

Brouwer, C. and Heibloem, M. (1986). Irrigation Water Management: Irrigation Water Needs. Training Manual No. 3.

Chan, S.C., Behera, S.K. and Yamagata, Y. (2008). Indian Ocean Dipole influence on South American rainfall. Geophysical Research Letters. 35, L14S12.

Chandrapala, L. 2007. Rainfall. pp. 58. In: National Atlas of Sri Lanka. $2^{\text {nd }}$ edition. Survey Department, Sri Lanka.

Clark, C.O. and Webster, P.J. (2003). Inter-decadal Variability of the Relationship between the Indian Ocean Zonal Mode and East African Coastal Rainfall Anomalies. Journal of Climate. $16,548-554$

De Costa, W.A.J.M. (2010). Adaptation of agricultural crop production to climate change: A policy framework for Sri Lanka. Journal of the National Science Foundation, Sri Lanka. 38 (2), 79-89.

DOA. (2018). Weather report, pp. 411-423. In: Peiris, P.C., Ranatunga, K.N.S., Sumith, J.A. Wasala, S.K. Malawiarachchi, M.A.P.W.K. and Kadupitiya, H.K. (Ed). Performance Report, Department of Agriculture.

Hapuarachchi H.A.S.U. and Jayawardena, I.M.S.P. (2015). Modulation of Seasonal Rainfall in Sri Lanka by ENSO Extremes. Sri Lanka Journal of Meteorology 1, 3-9.
Hong, C., Li, T. and Ho, L. (2008). Asymmetry of the Indian Ocean Dipole. Part I: Observational Analysis. Journal of Climate. 21, 4834-4848.

Jayawardene, H.K.W.I., Jayawardene, D.R. and Sonnadara, D.U.J. (2015). Inter-annual variability of precipitation in Sri Lanka. Journal of the National Science Foundation of Sri Lanka. 43 (1), 75-82.

Kousky, V.E. and Higgins, R.W. (2007). An alert classification system for monitoring and assessing the ENSO cycle. Climate Prediction Centre, Maryland, Weather and Forecasting. 22, 353-371.

Mcphaden, M.J., Zebiak, S.E. and Glantz, M.H. (2006). ENSO as an integrating concept in earth science. Science. 314 (5806), 1740-1745.

Pentakota, S., Gnanaseelan, C. and Prasad, K.V.S.R. (2012). Influence of El Niño and Indian Ocean Dipole on sea level variability in the Bay of Bengal. Global and Planetary Change. 80-81.

Philander, S.G.H. (1985). El Niño and La Niña. Journal of the Atmospheric Sciences. 42 (23), 2652-2662.

Punyawardena, B.V.R. (2020). Climate. pp. 13-22. In: Mapa, R.B. (Ed.) The Soils of Sri Lanka. Springer, Switzerland.

Punyawardena, B.V.R., Dissanaike, T, and Mallawatantri, A. (2013). Spatial variation of climate change induced vulnerability in Sri Lanka. Department of Agriculture, Peradeniya, Sri Lanka, pp. 1-2.

Punyawardena, B.V.R. (2008). Rainfall and Agroecological Regions of Sri Lanka (Sinhala). Department of Agriculture, Peradeniya, Sri Lanka. pp 43.

Punyawardena, B.V.R., Bandara, T.M.J., Munasinghe, M.A.K. Jayaratna Banda, N. (2003). Agro Ecological Regions of Sri Lanka (Map), Department of Agriculture, Sri Lanka.

Rao, S.A. and Yamagata, T. (2004). Abrupt termination of Indian Ocean dipole events in response to intra-seasonal disturbances. Geophysical Research Letters. 31, L19306.

Rao, S.A., Gopalakrishna, V.V., Shetye, S.R. and Yamagata, T. (2002). Why were cool SST anomalies absent in the Bay of Bengal during the 1997 Indian Ocean Dipole Event? 
Geophysical Research Letters. 29 (11). https://doi.org/10.1029/2001GL014645

Reynolds, R.W., Smith, T.M., Liu, C., Chelton, D.B., Casey, K.S. and Schlax, M.G. (2007). Daily high resolution blended analyses for sea surface temperature. Climate. 20, 5473-5496.

Saji, N. H., Goswami, B.N., Vinayachandran, P.N. and Yamagata, T. (1999). A dipole mode in the tropical Indian Ocean. Nature. 401, 360-363.

Verdon-Kidd, D.C. (2018). On the classification of different flavours of Indian Ocean Dipole events. International Journal of Climatology. September 2018, 1-14.

Webster, P.J., Moore, A.M., Loschnigg, J.P. and Leben, R.R. (1999). The great Indian Ocean warming of 1997-98: Evidence of coupled oceanic-atmospheric instabilities. Nature. 401, 356-360.
Xin-Yu, D., Na, L. and Shuanglin, L. (2015). The Connection between the Sea Surface Height Anomaly Preceding the Indian Ocean Dipole and Summer Rainfall in China. Atmospheric and Oceanic Science Letters. 8(4), 238-243.

Yamagata, T., Behera, S.K., Rao S.A., Guan, Z., Ashok, K. and Saji, N.H. (2002). The Indian Ocean dipole: A physical entity. CLIVAR Exchanges. 24, 15-18.

Yuan, Y., Yang, H., Zhou, W. and Li, C. (2008). Influences of the Indian Ocean dipole on the Asian summer monsoon in the following year. International Journal of Climatology. 28, 18491859.

Zubair, L. Rao, S.A. and Yamagata, T. (2003). Modulation of Sri Lankan Maha rainfall by the Indian Ocean Dipole. Geophysical Research letters. 1063. 